\title{
Study on the Implementation of Drainage System at Universiti Tun Hussein Onn Malaysia (UTHM)
}

\section{Kajian Perlaksanaan Sistem Saliran di Universiti Tun Hussein Onn Malaysia (UTHM)}

\author{
Mohd Luqman Ismail $^{1 *}$, Sharifah Meryam Shareh Musa ${ }^{1}$ \\ ${ }^{1}$ Fakulti Pengurusan Teknologi dan Perniagaan, \\ Universiti Tun Hussein Onn Malaysia, Johor, MALAYSIA \\ *Corresponding Author
}

DOI: https://doi.org/10.30880/jts.2021.12.02.002

Received 08 September 2020; Accepted 22 October 2020; Available online 12 January 2021

\begin{abstract}
Drainage systems play an important role in the development of managing surface runoff water. This is because without proper management of the drainage system, it can cause flooding in the area. Universiti Tun Hussein Onn Malaysia (UTHM) has suffered floods and caused significant losses. Therefore, the purpose of this article is to study the types of drainage systems available around the UTHM area. In this regard, semi-structured interviews were conducted with a number of respondents from the Development and Maintenance Office UTHM to study the problems of each existing drainage system around the area and to look at ways of improving the existing drainage system. The types of drainage systems available at UTHM have been identified as conventional drainage systems, Urban Stormwater Management Manual (MSMA), monsoon drainage, main drainage and land drainage. Problems such as drainage system, waste and clogged drainage also being identified. Among the improvements identified is replacing MSMA with open drainage. In conclusion, the study of drainage system implementation at UTHM can provide a clearer picture of the drainage system used around the study area.
\end{abstract}

Keywords: Drainage system, conventional drainage system, MSMA, UTHM

\begin{abstract}
Abstrak: Sistem saliran merupakan satu sistem yang penting dalam sebuah pembangunan bagi menguruskan air larian permukaan. Tanpa pengurusan sistem saliran yang baik, pelbagai masalah berkaitan air akan terjadi. Universiti Tun Hussein Onn Malaysia (UTHM) pernah mengalami masalah-masalah banjir yang menyebabkan pelbagai kesan sampingan kepada universiti. Oleh itu, tujuan artikel ini adalah untuk mengkaji jenis-jenis sistem saliran yang terdapat di sekitar kawasan UTHM. Seterusnya, temubual semi-struktur dijalankan ke atas beberapa orang responden daripada Pejabat Pembangunan dan Penyenggaraan UTHM bagi mengkaji masalah-masalah bagi setiap sistem saliran sedia ada di sekitar kawasan tersebut dan mengkaji kaedah penambahbaikan bagi mengatasi masalah sistem saliran yang berlaku. Jenis-jenis sistem saliran yang terdapat di UTHM telah dikenalpasti iaitu sistem saliran konvensional, Manual Saliran Mesra Alam (MSMA), saliran monsun, saliran utama dan parit tanah. Masalah-masalah seperti kecerunan sistem saliran, sampah-sarap dan saliran tersumbat menyebabkan sistem saliran tidak dapat berfungsi dengan baik. Antara kaedah penambahbaikan yang dikenalpasti adalah menggantikan MSMA dengan saliran terbuka. Secara kesimpulannya, kajian pelaksanaan sistem saliran di UTHM dapat memberikan gambaran yang lebih jelas mengenai sistem saliran yang digunapakai di sekitar kawasan kajian.
\end{abstract}

Kata Kunci : Sistem saliran, saliran konvensional, MSMA, UTHM 


\section{Pengenalan}

Sistem saliran memainkan peranan yang penting dalam sesebuah pembangunan bagi menguruskan air larian permukaan apabila berlakunya hujan. Pembangunan tanah boleh mendatangkan kesan terhadap persekitaran sesuatu kawasan seperti hakisan tanah yang menyebabkan sungai menjadi cetek dan berlakunya kejadian banjir kilat (Zainal, Kamarudin, \& Azlizan, 2014). Masalah limpahan air larian permukaan sering berlaku di sekitar kawasan Universiti Tun Hussein Onn Malaysia (UTHM). Hal ini disebabkan hujan yang turun terlalu lebat dengan tempoh masa yang lama dan menyebabkan limpahan air di sekitar kawasan UTHM. Limpahan air tersebut menyebabkan landskap di kawasan tersebut ditenggelami air dan air yang melimpah boleh mencecah bahagian koridor bangunan. Sistem saliran di UTHM terbahagi kepada tiga fasa pembinaan. Sistem saliran di kawasan bangunan asal semasa UTHM dikenali sebagai Institut Teknologi Tun Hussein Onn (ITTHO) menggunakan kaedah konvensional iaitu sistem saliran terbuka. Konsep saliran terbuka telah menimbulkan masalah yang boleh menyebabkan saliran tersumbat seperti sampah sarap berkumpul di dalam saliran, rumput tumbuh di tepi dan dalam saliran serta kelodak tanah dan batu-batu kecil akan masuk ke dalam saliran. Permasalahan sebegini menyebabkan sistem saliran tidak dapat berfungsi dengan baik dan boleh menyebabkan berlakunya limpahan air keluar daripada sistem saliran. Oleh itu, kajian dilakukan untuk mengkaji pelaksanaan sistem saliran dalam menguruskan air larian permukaan di sekitar kawasan UTHM.

Kejadian banjir merupakan perkara yang sering kali terjadi apabila berlaku hujan lebat di sesuatu tempat dan juga berpunca daripada sistem saliran yang tidak sistematik (Haliza, 2007). Banjir boleh terjadi apabila air sungai melimpah dari tebingnya dan limpahan ini berlaku akibat hujan lebat tanpa henti untuk tempoh beberapa hari di lokasi tertentu (Pah Rokiah, Rahim, \& Hamidi, 2014). Sistem perparitan yang tidak diurus secara berkesan menyebabkan banyak sistem saliran utama tersumbat. Longkang yang tersumbat dan tidak diselenggara dengan baik boleh mencetuskan masalah baharu terutama jika berlakunya kejadian hujan lebat dan akhirnya menyebabkan berlakunya banjir kilat. Kejadian banjir kilat sangat berkait rapat dengan keupayaan saliran menampung lebihan air hujan yang sepatutnya menyerap masuk ke dalam tanah. Berbanding di kawasan hutan atau luar bandar, kejadian banjir kilat yang dikaitkan dengan ketidakseimbangan air bandar adalah lebih kompleks kerana penglibatan manusia yang merubah sistem hidrologi semulajadi. Bencana banjir mempunyai potensi dalam menyumbang kepada kemusnahan harta benda dan kehilangan nyawa yang signifikan (Pah Rokiah, Baharum, \& Hamidi, 2015). Masalah pengurusan sistem saliran telah menjadi satu isu yang besar dan membawa cabaran kepada pihak kerajaan. Sehingga tahun 2001, kaedah pengurusan secara penyaliran cepat dikatakan telah menyebabkan peningkatan kejadian banjir kilat di kawasan pembangunan baru akibat air larian permukaan yang lebih tinggi, kenaikan mendadak puncak air, tempoh aliran lebih pendek dan lain-lain. Selain itu masalah air tercemar, sampah sarap terapung, dan pemendapan dalam sistem sungai semakin meningkat disebabkan oleh kelemahan dalam amalan semasa (Chan, Koh, \& Aminuddin, 2006). Peningkatan kepada kejadiankejadian banjir ini telah memberi satu tindakan yang proaktif kepada Jabatan Pengairan dan Saliran (JPS) untuk memperkenalkan buku panduan penyaliran bandar baru bagi menggantikan manual yang sedia ada. Ini adalah kerana manual ini telah digunakan sebagai garis panduan lebih daripada dua puluh lima tahun sejak penerbitannya dan tiada sebarang perubahan yang dibuat walaupun telah terdapat banyak pembangunan teknologi yang baru dalam sistem saliran bandar (Azazi, Aminuddin, Lariyah, Rozi, \& Hamid, 2002). Oleh yang demikian, pihak kerajaan dengan bantuan JPS telah memperkenalkan Manual Saliran Mesra Alam (MSMA) pada tahun 2001. Kerajaan telah menyarankan agar semua pembangunan baru menggunakan MSMA dalam merekabentuk sistem salirannya (Utusan Online, 2017).

Pengurusan banjir bersepadu adalah satu kaedah yang digunakan dalam pengurusan banjir yang menggabungkan semua aspek pengurusan banjir. Di mana kaedah pengurusan banjir secara berstruktur, tak berstruktur dan melibatkan pelbagai pihak yang bertanggungjawab dan komuniti di dalam pengurusan banjir sebagai elemennya (Sharifah Meryam, Chan, Ruhana, \& Zaini, 2013). Di Malaysia, MSMA digunakan sebagai alat dalam pengurusan banjir bersepadu. MSMA diwujudkan dengan matlamat untuk menyediakan panduan kepada semua pihak yang terlibat dalam perancangan dan mereka bentuk pengurusan air ribut. Manual ini mencakupi perancangan, asas reka bentuk, luahan banjir, reka bentuk saluran terbuka, struktur, storan, kawalan hakisan dan pemendapan (Sharifah Meryam, Chan, Ruhana, \& Zaini, 2013). Ia adalah bertujuan untuk mengenal pasti satu arah baru untuk pengurusan air ribut di kawasan bandar di Malaysia. MSMA memberi penekanan kepada konsep kawalan pada punca (control at source) iaitu melalui kaedah simpanan (storage-oriented approach) (Azazi, Aminuddin, Lariyah, Rozi, \& Hamid, 2002). Tujuan utama pendekatan baru ini adalah untuk mengawal pertambahan kadar alir hasil daripada pembangunan. Melalui kaedah ini kualiti dan kuantiti air larian dari kawasan pembangunan akan dikekalkan sama seperti keadaan sebelum pembangunan (Sharifah Meryam, Chan, Ruhana, \& Zaini, 2013). Dengan adanya manual ini masalah banjir yang berpunca daripada sistem saliran dapat diatasi jika saliran ini dilaksanakan mengikut aspek yang telah ditetapkan (Utusan Online, 2016). Ini kerana, banjir akan memberi kesan yang buruk dan menyebabkan kerosakan harta benda serta penyakit disebabkan air.

\section{Kajian Lepas}

Hidrologi adalah kajian yang berkaitan dengan kelakuan air atau cecair lain khususnya dari segi pergerakannya (Wilson, 1994). Pengetahuan tentang hidrologi penting untuk merekabentuk sistem perparitan yang sistematik. 
Faktor-faktor yang mempengaruhi kitaran hidrologi terdiri daripada aktiviti pembalakan dan proses pembandaran. Pada masa kini, pelbagai kajian telah dilakukan untuk melihat keberkesanan saliran untuk mengawal kejadian banjir di Malaysia. Sistem saliran berfungsi untuk menyalirkan air larian permukaan dari kawasan bangunan, kawasan berturap, kawasan jalan dan kawasan lain yang tidak telap air ke kawasan yang selamat seperti sungai dan tasik. Sistem saliran yang baik mestilah mampu untuk menampung kapasiti air larian yang diterima (Hamel, Daly, \& Fletcher, 2013). Terdapat beberapa jenis sistem saliran yang digunapakai bagi menguruskan air larian permukaan. Sistem saliran permukaan merangkumi pembuangan air lebihan melalui pengaliran graviti untuk menghalang pembentukan air pada permukaan tanah (Kumar, 2006). Sistem ini meliputi longkang atau parit tepi jalan, pembentungan, paip air larian dan struktur lain yang direkabentuk untuk membawa air larian permukaan. Sistem saliran sub-permukaan merupakan paip yang diletakkan dibawah permukaan tanah dan ditutup (Kapoor, 2005). Paip tersebut dipasang dengan penapis dan diletakkan pada kedalaman 1 hingga 2 meter. Air daripada sistem sub-permukaan yang ditapis akan dikumpulkan pada paip ini dan dialirkan keluar melalui rangkaian sub-pengumpul, pengumpul dan sistem saliran utama. pembersihan sebagai perawatan awal sebelum ianya dialirkan ke parit atau sungai berhampiran (Bio-Ekologikal, 2004).

Seterusnya, sistem saliran konvensional menekankan kepada konsep pembuangan cepat atau rapid disposal bagi air larian permukaan. Kaedah pembuangan segera ini menggunakan konsep pengaliran air larian keluar dari sesuatu kawasan dengan seberapa cepat yang mungkin. Manual Saliran Mesra Alam (MSMA) pula diperkenalkan untuk menggantikan manual saliran sebelum ini iaitu "Planning and Design Procedures No.1: Urban Drainage Design Standards and Procedure for Peninsular Malaysia" yang telah diterbitkan pada tahun 1975. Manual tersebut telah diamalkan selama 25 tahun dan tidak ada penambahbaikan pernah dibuat ke atasnya walaupun teknik dan teknologi dalam pengurusan air ribut telah berubah dan berkembang dengan pesatnya (Chang, Zakaria, Alias, Hashim, \& Gan, 2018). Air ribut perlu diurus kerana pembangunan yang pesat telah mengubah hidrologi dan hidraulik kawasan tadahan (Sharifah Meryam, Chan, Ruhana, \& Zaini, 2013). Menyedari hakikat bahawa sistem pengurusan air ribut di sesuatu kawasan perlu ditambahbaik, kerajaan telah menetapkan bahawa semua infrastruktur saliran di kawasan pembangunan baru dikehendaki mematuhi keperluan manual saliran baru sejak Januari 2001. Melalui pendekatan baru ini pemaju dikehendaki mengekalkan aspek kualiti dan kuantiti air larian pada tahap yang sama sebelum dan selepas pembangunan dijalankan.

Secara amnya, sistem saliran dipengaruhi oleh dua faktor iaitu faktor fizikal dan faktor iklim setempat (Syahril, 2003). Faktor fizikal terdiri daripada jenis tanah, topografi, corak guna tanah, keluasan kawasan tadahan dan tumbuhan tutup bumi. Faktor iklim setempat pula terdiri daripada tempoh keamatan hujan, hujan silam dan kelembapan tanah awalan, taburan dan kekerapan hujan. Terdapat beberapa masalah pada sistem saliran terutamanya yang melibatkan tumbuh-tumbuhan dan mendapan (Mariana, 2006). Antara masalah pada sistem saliran ialah paras air bumi yang tidak stabil, bau yang tidak menyenangkan, menjadi tempat pembiakan nyamuk, kesan kepada tanah dan kesesakan lalulintas. Daya tampung yang kurang untuk membawa air larian hujan akan menyebabkan limpahan air keluar daripada sistem saliran. Tambahan lagi, sistem saliran yang tersumbat akan menyebabkan fungsi saliran kurang efisien. Hal ini disebabkan air yang mengalir akan tersekat oleh sampah-sarap dan mendapan tanah dalam sistem saliran yang terbuka seperti sistem saliran konvensional. Terdapat dua kaedah untuk mengawal kuantiti air larian permukaan iaitu kaedah agihan dan kaedah simpanan (Razafli, 2008). Kaedah penambahbaikan pada sistem saliran pula adalah dengan menggunakan sistem saliran bio-ekologikal (BIOECODS). Konsep sistem saliran bio-ekologikal (BIOECODS) adalah sejajar dengan konsep MSMA iaitu pengekalan kitaran air hujan dalam sistem ekologi (Bio-Ekologikal, 2004). Komponen-komponen BIOECODS antaranya ialah alur berumput atau swale, dan kolam takungan kering (dry pond) atau kolam basah (wet pond). Komponen ini adalah kombinasi kepada proses penyusupan, melambatkan aliran, penyimpanan dan pembersihan sebagai perawatan awal sebelum ianya dialirkan ke parit atau sungai berhampiran (Zakaria, Ghani, \& Chang, 2014)).

\section{Metodologi Kajian}

Kajian ini menggunakan kaedah kualitatif pemerhatian dan temubual semi-struktur. Temubual semi-struktur membolehkan penyelidik bebas menemubual responden berdasarkan jawapan responden kepada satu soalan formal yang telah disoal (Chua, 2006). Temubual dijalankan bersama jurutera dan penolong jurutera bahagian awam di Pejabat Pembangunan dan Penyenggaraan UTHM (PPP). Responden bagi kajian ini merupakan mereka yang terlibat secara langsung dengan pelaksanaan sistem saliran yang terdapat di UTHM. Bagi setiap sesi temubual, penyelidik mengunakan alat perakam suara dan mencatat segala data yang diberikan oleh responden. Berdasarkan sesi temubual, penyelidik telah memperoleh banyak maklumat serta pandangan daripada responden. Maklumat yang diperoleh akan dianalisis untuk memberi gambaran yang lebih jelas berkaitan kajian yang dijalankan. Analisis kualitatif merupakan kepercayaan, pemahaman, pendapat dan pandangan responden (Fellows \& Kiu, 2002). Ketika proses ini dijalankan, penyelidik menganalisis semua pandangan, pengalaman, pertimbangan serta cadangan sama ada daripada responden atau data sekunder yang dihubungkaitkan untuk mencapai objektif yang telah ditetapkan. 


\section{Hasil Kajian dan Perbincangan}

Kajian pelaksanaan sistem saliran di UTHM adalah berteraskan kepada tiga objektif utama iaitu mengkaji jenisjenis sistem saliran yang terdapat di sekitar kawasan UTHM, mengenalpasti masalah-masalah bagi setiap sistem saliran tersebut dan mengkaji kaedah penambahbaikan bagi mengatasi masalah sistem saliran yang berlaku. Kesemua objektif kajian meliputi persekitaran di UTHM. Seterusnya, analisis kandungan dibahagikan mengikut objektif kajian untuk memudahkan data dianalisis. Analisis kandungan dibuat dalam bentuk jadual untuk memberi gambaran yang jelas berkaitan maklumat daripada responden.. Analisis data kajian dibantu dengan gambar dan pernyataan untuk menerangkan gambaran mengenai data kajian.

\subsection{Jenis-jenis Sistem Saliran yang Terdapat di UTHM}

Berdasarkan kenyataan responden yang ditemubual, terdapat lima jenis sistem saliran yang digunapakai di Universiti Tun Hussein Onn Malaysia (UTHM). Yang pertama ialah sistem saliran konvensional. Sistem saliran konvensional merupakan sistem saliran yang menekankan kepada konsep pembuangan cepat atau rapid disposal bagi air larian permukaan. Sistem saliran konvensional mempunyai konsep dan reka bentuk yang berbeza. Hal ini disebabkan kesesuaian sistem saliran tersebut yang terdiri daripada longkang dengan pelbagai saiz untuk mengalirkan air buangan atau air larian pada sesuatu kawasan. Antara konsep dan reka bentuk sistem saliran konvensional ialah longkang terbuka, longkang bentuk $\mathrm{V}$, longkang bentuk $\mathrm{U}$ dan longkang perimeter. Longkang-longkang tersebut mempunyai kedalaman yang berbeza. Dapat disimpulkan bahawa sistem saliran konvensional adalah sistem saliran terbuka seperti di Jadual 1.

Selain itu, jenis sistem saliran yang kedua ialah Manual Saliran Mesra Alam (MSMA). MSMA merupakan sistem saliran yang mengawal air larian pada sumber atau puncanya. MSMA berperanan untuk mengurangkan kelajuan air yang mengalir melalui kaedah penyusupan air ke dalam tanah. MSMA juga mengambilkira langkah yang berkesan untuk mengurus air lebihan hujan dan air larian permukaan dengan cara seperti storan, parit resapan, takungan dan sebagainya. Kaedah simpanan dapat mengurangkan isipadu air larian permukaan di dalam sistem saliran pada masa tertentu (Razafli, 2008). Menerusi sesi temubual, responden menyatakan terdapat beberapa jenis komponen yang digunakan dalam sistem saliran MSMA di UTHM. Komponen-komponen yang dinyatakan adalah kolam takungan, alur berumput, parit penyerapan, sistem longkang tertutup dan kolam takungan yang terdiri daripada kolam takungan basah dan kering. Komponen ini adalah kombinasi kepada proses penyusupan, melambatkan aliran, penyimpanan dan pembersihan sebagai perawatan awal sebelum air dialirkan ke parit atau sungai berhampiran (Bio-Ekologikal,2004). Manual Saliran Mesra Alam yang digunapakai di UTHM ditunjukkan pada Jadual 1.

Jenis sistem saliran yang ketiga ialah saliran monsun. Saliran monsun merupakan sistem saliran yang bersaiz besar untuk mengalirkan kapasiti air larian yang lebih banyak. Tebing saliran monsun biasanya dibina menggunakan batu gabion sebagai tembok penahan. Batu gabion berperanan untuk mengelak daripada berlaku hakisan dan mendapan tanah pada saliran monsun. Seterusnya, jenis sistem saliran yang keempat ialah saliran utama. Saliran utama merupakan saliran yang mengumpul air larian daripada sistem saliran permukaan dan saliran sub-permukaan untuk mengalirkan air ke dalam tasik atau sungai. Saliran utama terdiri daripada saliran bawah tanah dan saliran di jalan raya. Akhir sekali, jenis sistem saliran yang kelima ialah parit tanah. Parit tanah banyak terdapat di sekitar kawasan UTHM. Parit tanah berfungsi untuk mengalirkan air larian pada permukaan jalan untuk mengelakkan air bertakung yang boleh membahayakan pengguna jalan raya. Sistem saliran permukaan meliputi longkang atau parit tepi jalan untuk membawa air larian permukaan (Kumar, 2006). Parit tanah akan menyerap air menerusi proses penyusupan ke dalam tanah dan air yang tidak dapat diserap akan dialirkan ke saliran yang lain. Sistem saliran monsun, saliran utama dan parit tanah ditunjukkan pada Jadual 1.

Tambahan lagi, responden ada menyatakan jenis sistem saliran yang bersesuaian dengan persekitaran di UTHM. Jenis sistem saliran tersebut ialah sistem saliran konvensional. Kesemua responden berpendapat sistem saliran konvensional merupakan satu sistem saliran paling efisien yang digunapakai di UTHM berbanding MSMA. Hal ini kerana MSMA tidak sesuai diaplikasikan di persekitaran UTHM disebabkan keadaan topografi dan geologi tanah itu sendiri. Persekitaran UTHM merupakan kawasan bentuk muka bumi yang mendatar dan tidak mempunyai bukit yang tinggi. Selain itu, persekitaran UTHM adalah kawasan bertanah gambut dan di dalam tanah itu mempunyai kandungan air yang tinggi. Proses penyerapan dan penyusupan air ke dalam tanah adalah tidak efisien untuk Manual Saliran Mesra Alam.

Sistem saliran konvensional mempunyai banyak kelebihan yang lain. Antara kelebihannya adalah saliran konvensional mudah untuk diselenggara. Kerja-kerja penyelenggaraan yang dilakukan adalah pembersihan dengan menggunakan penyembur air bertekanan tinggi. Kerja pembersihan dilakukan untuk membuang tanah, sampah dan rumput yang terdapat di dalam sistem saliran konvensional seperti longkang konkrit. Sistem saliran konvensional juga mempunyai daya ketahanan yang kuat iaitu susah untuk berlaku masalah seperti saliran pecah dan mendap. Hal ini dapat mengurangkan kos untuk menyelenggara jika berlaku kerosakan. 
Jadual 1 - Jenis-jenis Sistem Saliran di UTHM

\begin{tabular}{lll}
\hline Jenis-jenis Sistem Saliran & Lokasi & Gambar \\
\hline Sistem saliran konvensional & Zon saliran kampus lama \\
& yang terdiri daripada \\
bangunan Blok B, Kolej \\
Kediaman Tun Syed Nasir \\
dan kawasan sekitarnya 1
\end{tabular}

Manual Saliran Mesra Alam (MSMA) Kawasan pembangunan fasa baru seperti bangunan perpustakaan, FSKTM, FKEE, FKAAS, FPTV, FPTP dan Bangunan G1 hingga G5

Saliran monsun

Saliran monsun terdapat di bahagian belakang Bangunan Pejabat Pendaftar

Saliran utama

Saliran utama terletak di sepanjang jalan masuk dan keluar pada pintu hadapan UTHM

Parit tanah

Parit tanah terdapat di bahagian tepi laluan utama atau jalan utama di UTHM 


\subsection{Masalah-masalah pada Sistem Saliran yang Terdapat di UTHM}

Kajian ini juga dijalankan bagi tujuan mengenalpasti masalah-masalah yang melibatkan sistem saliran di sekitar kawasan UTHM menerusi sesi temubual yang dijalankan. Sistem saliran yang digunapakai di UTHM terbahagi kepada dua iaitu sistem saliran konvensional dan Manual Saliran Mesra Alam (MSMA). Kedua-dua saliran ini terdapat masalah-masalah yang mengakibatkan sistem saliran tidak dapat berfungsi dengan baik. Masalah-masalah seperti kecerunan sistem saliran, air bertakung di dalam sistem saliran, masalah jentik-jentik, sampah sarap, saiz sistem saliran, saliran tersumbat dan sebagainya.

Masalah pada sistem saliran konvensional adalah kecerunan yang rendah. Kecerunan hendaklah ditentukan dengan tepat bagi mendapatkan aliran air yang berterusan (Syazwani, 2006). Akan tetapi, zon saliran kampus lama lebih rendah daripada kawasan zon saliran kampus baru. Hal ini menyebabkan air di dalam sistem saliran tidak dapat dialirkan dengan efisien. Air larian daripada kawasan kampus lama perlu dialirkan ke kawasan kampus baru dan air tersebut akan disalirkan ke tasik di hadapan Bangunan G3. Tasik tersebut juga lebih tinggi sebanyak 1 meter daripada kawasan zon saliran kampus lama. Oleh itu, penggunaan pam air diperlukan untuk mengalirkan air pada sistem saliran zon kampus lama ke bahagian tasik. Selain itu, saiz saliran yang kecil merupakan salah satu masalah sistem saliran konvensional. Sistem saliran yang baik mampu menampung kapasiti air yang banyak. Namun, longkang konkrit yang bersaiz kecil tidak dapat menampung kapasiti air larian yang banyak. Jika berlaku hujan lebat, air akan melimpah keluar daripada sistem saliran tersebut yang boleh mengakibatkan banjir. Banjir yang berlaku boleh menyebabkan kerosakan harta benda di sekitar bangunan dan juga di dalam bangunan jika air memasuki bangunan. Masalah-masalah lain terdiri daripada masalah sampah sarap dan rumput yang terdapat dalam sistem saliran terbuka seperti longkang konkrit yang ditunjukkan di Jadual 2. Terdapat juga masalah air bertakung di dalam longkang yang boleh menjadi tempat pembiakan jentik-jentik.

Masalah pada Manual Saliran Mesra Alam pula ialah faktor persekitaran. MSMA tidak sesuai diaplikasikan di kawasan tanah rendah seperti persekitaran UTHM. MSMA sesuai untuk persekitaran berbukit dan kawasan bertanah laterit untuk penyerapan air yang lebih efisien. MSMA menggunakan konsep penyerapan air untuk mengurangkan kelajuan air yang mengalir. Namun begitu, penyerapan air ke dalam tanah adalah tidak efisien disebabkan persekitaran UTHM mempunyai tanah jenis gambut yang tinggi kandungan air di dalamnya. Persekitaran UTHM juga terdapat banyak pokok-pokok besar yang mempunyai akar yang keras. Akar-akar tersebut boleh menembusi saliran paip di dalam tanah dan menyebabkan saliran tersebut pecah dan tersumbat. Struktur paip yang digunakan pada sistem saliran ini juga tidak mempunyai daya ketahanan yang kuat. Selain itu, kos yang tinggi dan kesukaran untuk selanggara merupakan antara masalah lain pada Manual Saliran Mesra Alam. Hal ini demikian kerana MSMA merupakan sistem saliran tertutup dan ditanam bawah permukaan tanah. Jika berlaku kerosakan pada paip, ianya tidak boleh diselenggara dan perlu penukaran paip yang baru. Tambahan lagi, batu-batu kecil yang terdapat pada permukaan atas sistem saliran ini yang berfungsi untuk menapis air larian permukaan telah bercampur dengan tanah. Daun-daun kering juga telah menutup permukaan batu-batu kecil ini yang menyebabkan penyusupan air terhalang. Sebagai contoh, kawasan Bangunan G3 yang menggunakan MSMA sering berlaku banjir apabila hujan lebat turun. Air yang melimpah daripada sistem saliran ke koridor bangunan akan menyebabkan permukaan lantai menjadi licin yang boleh membahayakan keselamatan pelajar. Persekitaran landskap bangunan juga ditenggelami air yang menyebabkan kesukaran kepada pelajar untuk ke tempat letak kenderaan. Masalah ini dapat ditunjukkan pada Jadual 2. Di samping itu, terdapat binatang berbisa seperti ular yang memasuki sistem saliran jenis ini. Kejadian tersebut berlaku di Kolej Kediaman Tun Fatimah. Saliran yang tertutup dan bersuhu dingin seperti jenis sistem saliran yang terdapat dalam MSMA mungkin menjadi tempat binatang berbisa seperti ular untuk berlindung. Ular tersebut berkemungkinan memasuki sistem saliran menerusi paip yang dihubungkan ke parit tanah seperti di Jadual 2. Oleh yang demikian, saliran tertutup yang digunapakai oleh MSMA boleh menjejaskan keselamatan pelajar-pelajar yang mendiami kolej kediaman tersebut. Tambahan lagi, menurut responden Manual Saliran Mesra Alam di UTHM tidak pernah dijalankan kerja-kerja penyelenggaraan. Beliau menyatakan sedemikian kerana pihak Pejabat Pembangunan dan Penyenggaraan tidak mempunyai kepakaran yang mendalam untuk kerja-kerja penyelenggaraan. Mereka tidak diberikan kaedah dan panduan secara teknikal untuk menyelenggara sistem saliran tersebut.

Di samping itu, masalah pada sistem saliran monsun adalah saiz saliran ini tidak mampu menampung kapasiti air yang tinggi jika berlaku hujan lebat yang berterusan. Ianya perlu diperbesarkan untuk memastikan air tidak melimpah keluar daripada saliran tersebut yang boleh menyebabkan banjir ketika hujan lebat berlaku. Semasa hujan lebat, paras air dalam saliran ini telah mencapai aras outlet yang menyebabkan air larian daripada saliran sub tidak dapat dialirkan. Selain itu, sebahagian saliran monsun masih menggunakan longkang tanah dan bersaiz kecil. Ianya perlu diperbesarkan lagi kerana saliran ini berfungsi untuk mengumpul air larian daripada kawasan bangunan kampus lama sebelum dialirkan ke dalam tasik. Saliran monsun yang terdapat di bahagian belakang Bangunan F1 tidak dapat menampung jumlah air yang banyak dan menyebabkan air larian melimpah keluar daripada tebing saliran. Hal ini menyebabkan pam air tidak dapat beroperasi dengan cepat kerana air larian di dalam saliran tersebut telah melimpah ke tebing saliran. Rajah 1(a) dan Rajah 1(b) menunjukkan keadaan saliran monsun semasa hujan lebat tidak berlaku dan semasa hujan berlaku. Dapat dilihat peningkatan paras air larian yang tinggi dan menyebabkan limpahan air ke tebing saliran. 


\section{Jadual 2 - Jenis-jenis Sistem Saliran di UTHM}

\begin{tabular}{l}
\hline Masalah Sistem Saliran \\
\hline Sampah sarap dan rumput yang
\end{tabular}
terdapat dalam sistem saliran terbuka seperti longkang konkrit yang melibatkan sistem saliran konvensional

Lokasi

Gambar

Zon saliran kampus lama yang

terdiri daripada bangunan Blok

$\mathrm{B}$ dan kawasan sekitarnya
Air melimpah daripada sistem saliran ke koridor bangunan yang melibatkan MSMA

Pesekitaran landskap bangunan ditenggelami air yang berpunca daripada sistem saliran jenis MSMA yang telah tersumbat
Persekitaran kafeteria di Bangunan G3

Persekitaran landskap di Bangunan G3
Saliran paip yang dihubungkan secara terbuka boleh menyebabkan binatang berbisa memasuki sistem saliran jenis MSMA
Saliran paip yang dihubungkan

ke parit tanah di Kolej

Kediaman Tun Dr Ismail (a)

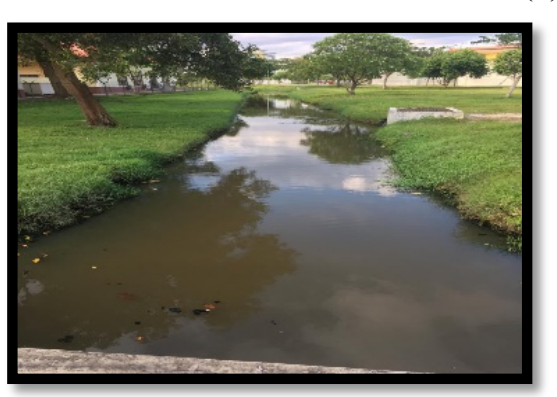

(b)

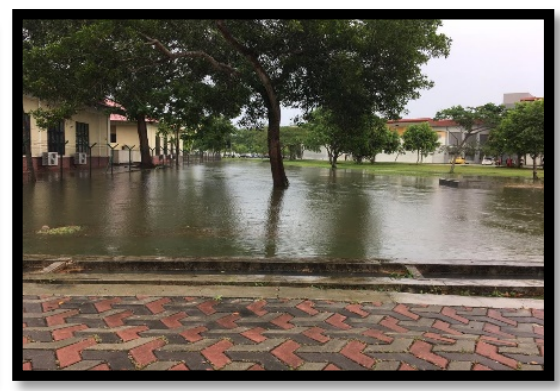

Rajah 1 - (a) Saliran monsun semasa hujan lebat tidak berlaku dan (b) saliran monsun semasa hujan lebat berlaku 


\subsection{Kaedah Penambahbaikan bagi Mengatasi Masalah Sistem Saliran yang Berlaku di Sekitar Kawasan UTHM}

Berdasarkan kenyataan yang diberikan oleh responden, kaedah penambahbaikan pada saliran konvensional adalah cara memotong rumput dan pemantauan semasa kerja-kerja selenggara dilakukan. Cara memotong rumput yang betul penting bagi memastikan rumput yang dipotong tidak memasuki longkang yang terbuka. Semasa kerja pemotongan rumput dilakukan, penghadang perlulah diletakkan di tepi saliran terbuka untuk menghalang rumput yang dipotong memasuki sistem saliran. Kerja-kerja selenggara seperti pembersihan longkang daripada mendapan juga perlu dipantau untuk memastikan longkang dibersihkan mengikut piawaian yang telah ditetapkan. Selain itu, kecerunan longkang perlu ditinggikan agar aliran air tidak tersekat pada sesuatu kawasan. Hal ini dapat memastikan tiada air bertakung yang boleh menjadi tempat pembiakan nyamuk. Kaedah penambahbaikan yang lain juga adalah melepa longkang konkrit yang mengalami keretakan untuk mengelakkan keretakan yang lebih besar berlaku. Akhir sekali adalah aras jalan raya yang terdapat di sekitar kawasan kampus lama telah ditinggikan untuk mengelakkan air melepasi paras jalan apabila berlaku hujan lebat. Sistem saliran yang terbuka boleh menyebabkan air melepasi tebing saliran dan menenggelamkan permukaan jalan.

Penambahbaikan pada Manual Saliran Mesra Alam adalah untuk menggantikannya dengan sistem saliran konvensional yang merupakan saliran terbuka. Hal ini kerana MSMA tidak sesuai untuk keadaan topografi dan geologi tanah yang terdapat di Universiti Tun Hussein Onn Malaysia (UTHM). Saliran tertutup yang digunapakai oleh MSMA sering berlaku kerosakan dan saliran tersumbat yang menyebabkan air larian tidak dapat dialirkan dengan baik. Tambahan lagi, pembangunan blok bangunan baru di Fakulti Kejuruteraan Elektrik dan Elektronik telah menggunakan sistem saliran konvensional sebagai sistem saliran di persekitaran bangunan itu. Sistem saliran konvensional adalah satu sistem saliran yang paling efisien untuk digunapakai di sekitar kawasan UTHM.

\section{Kesimpulan}

Secara kesimpulannya, sistem saliran konvensional merupakan sistem saliran yang paling efisien untuk digunapakai di UTHM. Masalah-masalah untuk setiap jenis sistem saliran turut dapat dikenalpasti di mana sistem saliran tertutup yang melibatkan penggunaaan Manual Saliran Mesra Alam (MSMA) tidak sesuai untuk diaplikasikan di persekitaran UTHM. Keadaan topografi dan geologi tanah merupakan faktor yang menyebabkan kurangnya keberkesanan MSMA. Selain itu, sistem saliran konvensional terdapat masalah yang melibatkan kecerunan sistem saliran. Kecerunan pada sistem saliran amat penting bagi memastikan air larian dapat mengalir dengan sempurna tanpa ada aliran air yang tersekat pada sesuatu kawasan. Di samping itu, terdapat beberapa kaedah penambahbaikan yang dilakukan pada sistem saliran untuk memastikan sistem saliran dapat berfungsi dengan baik. Kaedah penambahbaikan tersebut dibahagikan kepada dua jenis sistem saliran iaitu sistem saliran konvensional dan Manual Saliran Mesra Alam. Untuk sistem saliran konvensional, kaedah penambahbaikan yang dilakukan adalah cara memotong rumput, memantau aktiviti penyelenggaraan yang dilakukan oleh pihak kontraktor, meninggikan kecerunan longkang konkrit, melepa longkang konkrit yang mengalami keretakan dan meninggikan aras jalan raya yang terdapat pada kawasan zon kampus lama. Untuk Manual Saliran Mesra Alam pula, kaedah penambahbaikan adalah MSMA yang gagal pada fungsinya digantikan dengan sistem saliran konvensional. Hal ini kerana sistem saliran konvensional dapat mengurangkan masalah saliran tersumbat yang disebabkan akar kayu yang menembusi paip saliran yang terdapat bawah permukaan tanah pada sistem saliran tertutup yang diguna pakai dalam Manual Saliran Mesra Alam. Pejabat Pembangunan dan Penyenggaraan UTHM juga perlu memainkan peranan dengan memastikan sistem saliran diselenggara dengan baik dan menyediakan jadual berkala untuk penyelenggaraan pada sistem saliran MSMA.

\section{Penghargaan}

Penulis ingin mengucapkan terima kasih kepada Fakulti Pengurusan Teknologi dan Perniagaan, Universiti Tun Hussein Onn Malaysia, Johor, MALAYSIA

\section{Rujukan}

Azazi Z., Aminuddin A. G., Rozi A., Lariyah M.S., Hamid K., Anita A. (2002). Saliran Mesra Alam Sebagai Sebahagian Dari Landskap Pembangunan. Universiti Sains Malaysia

Chan N.W., Koh H. L. \& Aminuddin A. G. (2006). Developing a model of flood hazards on urban floodplains in Malaysia. Dlm. Abd. Aziz Tajuddin \& K.O. Lim (Ed.) Fundamental Research at USM 2002 - 2005 Vol. 3 (Arts). Penang: Penerbit Universiti Sains Malaysia, 32-54

Chua, Y. P. (2006). Kaedah Penyelidikan. Kuala Lumpur. Mgraw Hill Malaysia Sdn. Bhd 
C. K. Chang, N. A. Zakaria, N. A. Alias, H. Abu Hashim \& S. H. Gan (2018). Sustainable Solutions to River Improvement Works Using Bio-Engineering Technique. Proc. of $21^{\text {st }}$ Congress of International Association for HydroEnvironment Engineering and Research (IAHR), Asia Pacific Division (APD). Multi Perspective Water for Sustainable Development, Yogyakarta, Indonesia. 2-5 September. 1461-1467

Fellows R. \& Liu A. (2003). Research Methods for Construction. 2nd Edition. Blackwell Publisher Garis Panduan Sistem Saliran Bio-Ekologikal (BIOECODS) di Malaysia, (2004). Reka Bentuk Komponen BIOECODS

Haliza, A. R. (2007). Suatu Tinjauan Terhadap Permasalahan Banjir Kilat Di Lembah Klang. Procedia Geography, 8(September), 1-15

Hamel P., Daly E., Fletcher T. D. (2013). Source-control stormwater management for mitigating the impacts of urbanisation on baseflow: A review. Journal of Hydrology 485, 201-211

Kapoor, A. S. (2005). Biodrainage- A Biological Option for Controlling Waterlogging and Salinity. Mcgraw Hill Publishing Company

Kumar, D. (2006). Irrigation Water Management Principle and Practice. Prentice Hall of India

Lariyah M.S., Kaoru T., Azazi Z., Aminuddin A. G. \& Rozi A. (2004), An Assesement of Stormwater Management Practices using MSMA manual in Malaysia

Manual Saliran Mesra Alam (2001). Urban Stormwater Management Manual for Malaysia. Volume 1-Introduction. Urban Stormwater Management Short Course

Manual Saliran Mesra Alam (2012). Urban Stormwater Management for Malaysia. Government of Malaysia Department of Irrigation and Drainage

Mariana Suzie, A. A. (2004). Sistem Perparitan di Taman Durandah Emas, Siburan, Kuching, Sarawak. Universiti Teknologi Malaysia. Tesis Sarjana Muda

Md Zan, Z., Ngah, K., \& Talib, A. (2014). Sustainable Urban Community Development Through Agenda 21. Journal of Techno Social, 6(1)

Mohd Ikhwan, T. (2000). Banjir Sebagai Bencana: Isu, Cabaran dan Pengurusannya di Malaysia. Pengurusan Persekitaran di Malaysia: Isu dan Cabaran. 127-146. UKM, Bangi

N. A. Zakaria, A. A. Ghani, and C. K. Chang, "MSMA 2 nd Edition-Application of Green Infrastructures for Solving Sustainable Urban Stormwater Management Challenges," 2014

Nor Syazwani, M. K. (2016). Aplikasi Penggunaan Sistem Saliran Mesra Alam. Kajian Kes: Pura Kencana, Batu Pahat, Johor. Universiti Tun Hussein Onn Malaysia. Tesis Sarjana Muda

Razafli (2008). Kajian Keberkesanan Penggunaan Kolam Takungan dalam Mengawal Air Larian Permukaan. Universiti Putra Malaysia. Tesis Sarjana Muda

Sharifah Meryam, S.M., Chan N. W., Ku Ruhana, K. M. \& M. Zaini, A.K (2013). Faktor Polisi dan Tindakan Pengurusan Banjir dalam Mempengaruhi Keberkesanan Pelaksanaan Manual Saliran Mesra Alam (MSMA). Prosiding Seminar Serantau Ke-2 Pengurusan Persekitaran di Alam Melayu

Tuan Pah Rokiah, S. H., Abd Rahim, M. N., \& Hamidi, I. (2014). The level of satisfaction towards flood management system in Kelantan, Malaysia. Pertanika Journal of Social Science and Humanities, 22(1), 257-269

Tuan Pah Rokiah, S. H., Mohamed, B., \& Ismail, H. (2015). Kesediaan Diri Anggota Masyarakat Daripada Perspektif Psikologi Berkaitan Bencana Banjir Di Daerah Segamat. Journal of Techno Social, 7(2)

Utusan Online (2017, Disember 24). 4.8 Juta Penduduk Terjejas. Utusan Online. 